\title{
Harnessing ICT to support the mixed-mode delivery framework
}

\author{
O uso das TIC no apoio de um modelo \\ pedagógico multiestratégico
}

\section{Koh Noi Keng}

Ph.D, professora do National Institute of Education e da Nanyang Technological University Cingapura, e-mail: noikeng@live.com.sg

\begin{abstract}
To teach the net generation in today's classrooms, it calls for innovative teaching and learning strategies that are engaging so as to sustain learners' interest in learning. This paper describes how Singapore has successfully launched ICT initiatives in schools and expounds the use of the Mixed Mode Delivery (MMD) pedagogical model in ICT-Rich classrooms in Singapore educational context. This paper discusses how ICT is harnessed so as to support the MMD model where student teachers are empowered with a wide repertoire of strategies and tools to create a more positive learning environment. The paper concluded with the remark on the importance of the MMD as a viable pedagogical model for sustaining interest of learners in a high-tech world.
\end{abstract}

Palavras-chave: ICT. Learning environment. Learners' perceptions and attitudes. Mixed-mode delivery. 


\section{Resumo}

Atualmente, para ensinar em sala de aula a geração que tem sido denominada de net, exige-se um ensino inovador e estratégias de aprendizagem engajadas de forma a sustentar o interesse dos alunos na aprendizagem. Este artigo descreve como Cingapura lançou, com sucesso, iniciativas para o uso das Tecnologias da Informação e Comunicação (TIC) em suas escolas e ainda apresenta o uso de um modelo pedagógico multiestratégico (Mixed Mode Delivery - MMD) em salas de aula, amplamente providas de ferramentas advindas das TIC. O estudo discute como as TIC são utilizadas para dar suporte ao modelo multiestratégico, no qual professores/estudantes dispõem de um vasto repertório de estratégias e ferramentas para criar um ambiente de aprendizagem mais positivo. O artigo conclui assinalando a importância do MMD como um modelo pedagógico viável para manter o interesse dos alunos no mundo da alta tecnologia.

Palavras-chave: TIC. Ambientes de aprendizagem. Percepções e atitudes do aprendiz. Modelo pedagógico multiestratégico.

\section{Introduction}

Information Communications Technology (ICT) has been leveraged upon to transform our learning environment in Singapore schools for more than 10 years now. Unlike previous approaches to using ICT which placed a high degree of structure or control on the learner, the new technology-rich classrooms provide an environment permitting more learner choices. Learners can explore and be responsible for their learning. The learning environment is essentially unlimited exploration and learning is more exciting. The learners become more engaged with the material; develop problem solving skills and critical thinking skills rather than just a passive receiver of content. The learning features available with the new technology tools make it possible to do more for the effective harnessing of ICT in teaching and learning in the classroom and beyond.

This paper provides a background of how Singapore launched ICT in schools and describes a pedagogical framework which is ICT-rich 
called the "Mixed-Mode Delivery" (MMD) model, provides teachers with more room to innovate in teaching and learning, and to move beyond the boundaries of the physical classroom. It subscribes the constructivist approach to learning, and is therefore based on the idea that the learner constructs his or her own knowledge through negotiation of meaning (HAND; TREAGUST; VANCE, 1997). According to Tobin and Tippins (1993), constructivism has been used as a referent for building a classroom that maximizes student learning. In such a classroom, the teacher takes account of what students know, maximizes social interactions between learners so that they can negotiate meaning, and provides a variety of sensory experiences from which learning is built.

\section{Background on Singapore education initiatives}

This section highlights current initiatives undertaken by Ministry of Education (MOE) Singapore and traces the development of the three ICT Masterplans: Masterplan 1, 2 and 3. Masterplan 3 aims to improve service delivery and competitive advantage through using ICT. Singapore invests substantially in ICT networks. By 2012, the Next Generation National Broadband Network under the iN2015 Masterplan will be ready to support ultra-high speed connectivity, creating new opportunities for our economy, government and society. Schools, in particular, will be able to tap on the increased bandwidth to enhance teaching and learning in our schools. The first Masterplan to achieve this was started more than a decade ago.

In line with the national infocomm Masterplan for Singapore Intelligent Nation 2015, MOE recently rolled out the Masterplan 3 (MP3) which aims to equip students with skills in a knowledge-based economy. Attached is an overview of the development of the MOE ICT master plans for Singapore:

a) first Masterplan for ICT in Education (1997-2002) - provision of basic ICT infrastructure in schools and in equipping teachers with a basic level of ICT integration competency;

b) second Masterplan for ICT in Education (2003-2008) - strengthening the integration of ICT into the curriculum, establishing baseline 
ICT standards for students, and seeding innovative use of ICT among schools;

c) third Masterplan for ICT in Education (2009-2014) - enriching and transforming the learning environments of our students and equip them with the critical competencies and dispositions to succeed in a knowledge economy.

Resources have been scaled up to implement ICT development projects as well as replacement of ICT equipment and network in schools. Currently five schools have been selected to pioneer the new Future Schools program to promote widespread use of ICT in innovative teaching approaches. All five schools have begun pilot implementation and are expected to reach full-school implementation by 2011. Initial learning points from Phase 1 schools will be used in selecting schools for subsequent phases. MOE targets to support up to 15 Future Schools by 2015. These Future Schools will in turn support Singapore's drive to become a global Interactive and Digital Media (IDM) capital and push the frontiers of teaching and learning on a school-wide level (MOE, 2008).

The broad strategies of the MP3 for ICT in Education are (i) to strengthen integration of ICT into curriculum, pedagogy and assessment to enhance learning and develop competencies for the 21st century; (ii) to provide differentiated professional development incorporating ICT models to help students learn better; (iii) to improve the sharing of best practices and successful innovations; and (iv) to enhance ICT provisions in schools to support the implementation of MP3. See Figure 1 for more details on the MP3.

Teachers in Singapore are now expert enough to produce their own digital content and expand the resource base for others to share. However, a gap continues to exist between familiarity with ICT and translating this into effective teaching. Over $30 \%$ of our teaching force is below the age of 30, and ICT-savvy. They own mobile phones and laptops, chat regularly on MSN Messenger and interact with friends on social networking sites such as Facebook. Some even have second and more lives on Second Life. However, it should not be assumed that they are more effective as teachers just because they are familiar with modern technology (NG, 2008). 


\section{Integration of ICT into Curriculum, Assessment \& Pedagogy}

ICT will be more extensively integrated into the planning, design and implementation stages of the curriculum, assessment and pedagogy. There will be greater alignment of students' learning outcomes in the syllabi, national examinations, and classroom experience to 21st century skills such as IT skills, and the ability to communicate persuasively and collaborate effectively. Students will be required to use ICT to look for information, synthesise reports, give feedback on each others' work and collaborate with peers within and outside school.

\section{Differentiated Professional Development}

School leaders can create the environment for teachers to reflect and review effective teaching practices incorporating ICT use in the classrooms which yielded desired learning outcomes for their students.

MOE will train a pool of "ICT specialist teachers" with strong pedagogical groundings to model and lead professional development efforts within and across schools. A learning roadmap will also be developed to help teachers in the effective use of ICT in their classes.

\section{Sharing of best practices and successful innovations}

To improve the sharing of best practices, MOE will support the establishment of a network of educational labs where innovations can be prototyped and tested. These labs will provide the latest technologies to promote exploration of learning possibilities. They can also serve as training ground for pre- and inservice teachers.

MOE will continue to support innovations in the use of ICT and facilitate sharing of good practices among schools through programmes like the FutureSchools@Singapore and LEAD ICT@Schools.

\section{Enhanced ICT Provisions}

Accessibility of ICT to students will be increased through more flexible and mobile infrastructure provisions such as wireless internet access, piloting 1-notebook-to-1pupil ratio in more schools, and higher data bandwidth.

Figure 1 - Masterplan 3

Source: MOE website. 
At the National Institute of Education (NIE) Singapore, we transform pedagogy through the use of ICT in the schools. There are six key research initiatives in ICT (LOOI; HUNG; BOPRY; KOH, 2004):

a) epistemologies of teachers toward the use of ICT;

b) student meaning-making with ICT;

c) teachers' design of learning activities with ICT;

d) design of learning Technologies;

e) scalability and sustainability;

f) school practices and policies.

The latest research that is currently happening, involves a survey of students' attitudes and perceptions towards the use of business simulation computer games in teaching and learning for a business subject that is taught to students in secondary schools. This study will provide a snapshot of the current state of ICT in schools, and our informant design game development process with teachers will inform us about the challenges faced towards a better appropriation of ICT in schools. The informant game design process will also involve students as contributors of inputs for game design and to test the game pilot modules. The game authoring tool we develop will be used in a classroom project-based learning approach to create a constructivist learning environment enabled by ICT. This game authoring tool also enables scalability and sustainability of the project as teachers and students will be able to continue the development of new game modules to be used in their own classrooms, and to be shared with other schools.

\section{Devising purposeful activities}

ICT savviness is useful but it is only a tool. The ICT-rich lessons and activities used in teaching and learning to achieve effective outcomes must be based on sound pedagogical principles. It is futile to have an exciting computer game that does not bring out key learning points. There are a lot of ICT tools out there, but we the educators must question whether they are used appropriately. Optimal use of ICT will ensure that curriculum time will not be wasted and students are focused on task. A simple worksheet assignment that students can read and do, can continue to be done using 
pen and paper. Similarly, surfing on the Internet to search for information must either be guided with the URL links before allowing them to go and do their own search outside class. What is important is the use of the new knowledge gleaned from the internet so that the students are able to have a rigorous discussion on the issues and use of knowledge meaningfully. This use of ICT neither transforms nor enhances the learning experience unless the value from this activity is a result of learning how to organize, synthesize and internalize the new information and skills.

In short, the use of ICT tools must be purposeful and must support teaching and learning and not merely be preoccupied with technical tasks of searching for information using the Internet and presenting using powerpoint. As an illustration, using WebQuest (DODGE, 2002), my pre-service teachers are assigned tasks, and in these well constructed tasks, they leverage on technological tools like discussion forums and wikis to create and write case studies after watching a videoclip and gathering data from other sources. In doing so, their classmates could critique them and they in turn, could refine their work after having considered all the different perspectives put forth. This is what we mean when we say harnessing ICT for effective teaching and learning in a Mixed-Mode Delivery (MMD) framework.

There are indications that the traditional models of learning, traditional definitions of technology effectiveness, and traditional models of cost effectiveness of technology do not prepare the next generation for the future workplace. Educators are seeking new ways of engaging learners in meaningful learning and collaboration, involving challenging and real-life tasks, and capitalizing on technology as a tool for learning and collaboration (AKAR, 2003). Hence, it is imperative that a pedagogical framework to empower change in current practices in schools is made available.

\section{The mixed-mode delivery model}

DePorter and Hernacki (2000, p. 4) "supported the view that students taught in their preferred learning style have improved attitudes towards learning, increased tolerance for different ways of learning, and increased academic achievement". The MMD framework advocates the alternative teaching paradigm that utilizes and familiarizes pre-service 
teachers with IT, such as the use of the MMD being studied in this thesis, is needed. It is recognized, however, that ICT is only a tool, albeit a powerful one, for achieving a constructivist learning environment. It is a means to an end, not an end in itself.

The MMD capitalizes on technology to achieve an optimal level of delivery to engage learners in learning. While the deployment and diffusion of e-learning in schools is becoming an almost irresistible force, careful consideration must be given to all aspects of e-learning and online education that might impact the quality, efficiency, equity and educational choices available to all learners. Therefore, teachers need to be prepared to give careful, systematic consideration to details that will have a lasting impact on learners.

ICT is harnessed to develop problem-solving skills and critical thinking skills, rather than just for the presentation of content $(\mathrm{KOH}$, 2004). This is consistent with the new paradigm, proposed by Barr and Tagg (1995), advocating that we should move from a learning environment that is teacher directed to one that provides for more learner options. The goals that teachers have set might not be congruent with those generated and defined by students. This vital difference between the demands of the learning environment and students' learning needs and perceptions of the learning environment can result in incongruence. In a study by Ylanne and Lonka (1999), it was found that students were confused about whether their learning environment was optimal for their learning, although they appeared to be quite sure of their purpose of studying. The problem seemed to be that their views differed from that of their lecturers. Ylanne and Lonka (1999) concluded in that study that a possible explanation is that the traditional curriculum did not provide the best environment for these students.

The MMD model embraces a wide variety of methodologies, which include cooperative learning, case studies, field trips, problem-based learning and strategies that are ICT-based, like WebQuest, mind-tools, e-learning, video vignettes, online games and internet-based discussion forums. The class dynamics and the teaching and learning styles are different from traditional teaching methods. Also, there must be authentic and purposeful tasks to bridge the gap between education and the world of work (RAINER; MATTHEWS, 2002). Andrews, Garrison and Magnusson (1996, p. 87) found in their interviews probing teaching excellence at the tertiary level that: 
the general concept [...] expressed was that excellent teachers use self-reflection to develop a model (either formal or informal) for teaching within a particular context; they then attempt to 'live the model', and be authentic to and congruent with their model.

\section{These ideas are embedded in the MMD model}

Besides face-to-face learning activities, e-learning is also one of the useful modes of delivery in the MMD model. One premise of e-learning in the MMD model is that web-based software enables instructional designs, including online lectures, e-portals and networked learning communities, to provide more usability, accessibility, convenience and value to learners.

Most teachers have come to realize that, when used constructively with students, technology is a 'potent mixture', as described by McKenzie (2000). "Through this alchemy, we are witnessing professionals who use technology in constructivist ways" (MCKENZIE, 2000, p. 4). Besides capitalizing on artificial intelligence, this researcher has also introduced the idea of authorship community involving teachers uploading their resources and students' good work to an online resources portal. The idea of an 'authorship society' results in large amount of resources. This creates new relationships between people and between members within our community, as well as challenging our notions of creativity itself.

Whether the delivery systems use face-to-face instruction or highly sophisticated online learning environments, it is how engaging the content and activities are in providing the most effective learning environments for students that ultimately matters. Because the exponential growth of ICT has brought about the availability of e-learning as a powerful tool, educators could harness it for teaching and learning. Unlike previous approaches to using ICT, which placed a high degree of structure or control on the learner, new technology-based instructional applications provide an environment that permits more learner choices. Students can explore and be responsible for their own learning.

The learning environment essentially allows almost unlimited exploration, with learning from mistakes being accepted and even encouraged 
as learners take calculated risks. Learners proceed through a vast amount of content in an often unstructured or even random manner. They also become more engaged with the materials, thereby developing their problem solving skills and critical thinking skills rather than just remaining as passive receivers of content. This mode of enquiry can be achieved through problem-based learning (PBL) or WebQuest.

WebQuests (DODGE, 2001) providelearning activities that involve practice in using critical thinking skills and are usually scenario based. They inject realism into a lesson and direct a more responsible use of the Internet. This philosophy of learning mirrors the philosophy of the process curriculum and the philosophy of authentic assessment. WebQuests provide structure and guidance and make good use of computer access by recognising qualities unique to the Internet, such as capturing dialogue through interactive forums using Blackboard and multimedia with video-streaming.

Problem-based learning (PBL) provides a rich learning environment, in which students identify what needs to be studied and learned from examining the problems confronted (GIBBS, 1992). The problems are used as a tool to achieve both the required knowledge base and the skills to 'solve' those (BARROWS, 1986). The basis of PBL is that students learn by doing. It is a student-centred system, whereby students, working within small groups, generate the information necessary for responding to or solving a real-life problem or task (BOUD; FELETTI, 1997). Barrows (2000) advocates an education process that requires the learner to go through the same activities during learning as those that are valued in the real world. The objective of doing this is to expose the learner to real-life problems both as a stimulus for learning and a focus for organizing what has been learned for later recall and application to future work, bridging the gap between theory and practice (TAN, 2004).

With the increased spread of the use of powerful new software, and hence rapid access to human resources, materials and information, learning opportunities have likewise expanded immensely. Students are now able to acquire, synthesize and reconstruct information in a way that was previously not possible. The more sophisticated technology systems now allow increased teacher-student interaction, cooperative learning and, most importantly, problem solving, inquiry and problembased learning. 
Students also take responsibility for their own learning process by reflecting on their experiences. The teacher helps to create situations in which students feel safe when questioning and reflecting on what they have learned, either privately or in group discussions. The teacher should also create activities that lead the student to reflect on his or her prior knowledge and experiences. Talking about what was learned and how it was learned are really important.

In fact, in reflective practice, pre-service teachers reflect not only on their sources of knowledge, attitudes and beliefs, but also on the effectiveness of their repertoire of strategies that underpin their instructional practice. They can make use of a blog, which is an online diary, or engage in an online chat or discussion forum with their classmates. The discussions thus far can best be depicted by showing the MMD set in the context of a larger environment as shown in Figure 2.

The Figure 2 shows the MMD set in the context of an environment driven by the demands of the knowledge-based economy and the changing profile of the net generation with different sets of needs and expectations. With the advent of ICT, the need to equip current generation of young people for the future workplace calls for changes in the curriculum so as to be relevant. Hence, such curricular reform in turn calls for a change in pedagogy and assessment in order to achieve the desired learning outcomes.

The MMD is a multi-faceted model that incorporates strategies that harness and integrate the ever-changing advances in ICT, not only now, but also in the years to come. People change, institutions change and ICT tools change. Saying that the world has seen exponential growth in advances in ICT over the last few years is an understatement. Thus, it is logically impossible to see the future even when studying the uses of artificial intelligences. For example, students are learning about future technology in the context of a present-day institution where individuals have been shaped by the era in which they live. Ironically, this is the situation with which the researcher has to grapple with. Teachers have to prepare their students for the future. They, therefore, have to be adept in employing pedagogical practices that will meet the needs of the net generation and prepare students for the future workplace. The MMD framework is therefore not static but will grow and continue to progress with new effective teaching and learning pedagogies. 


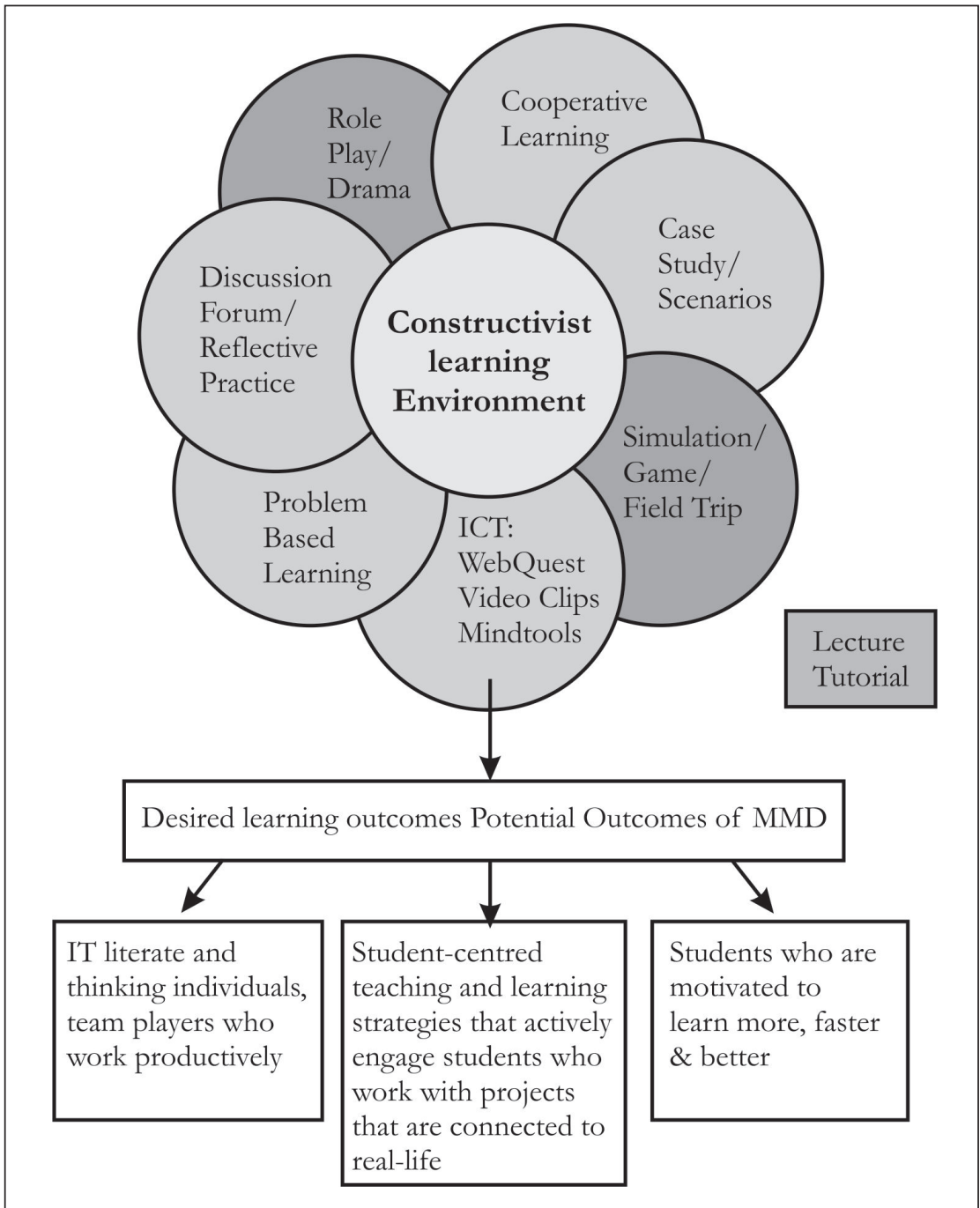

Figure 2 - The Outcomes of the Mixed-Mode Delivery (MMD) Model

By adopting a constructivist paradigm in the MMD framework, the large-scale integration of different useful and productive pedagogical approaches becomes possible. Such a paradigm also allows simulation and online educational games as an extension of this pedagogy. 
With the expansion of learning opportunities, as well as the rapid access to human resources, materials and information through powerful new software, students are able to acquire, synthesize and reconstruct information. Studies(COGNITIONANDTECHNOLOGYGROUPATVANDERBILT, 1993; JONASSEN, 1996) of impact of these more sophisticated technology systems showed increased teacher-student interaction, cooperative learning and, most importantly, problem solving, inquiry and problem-based learning. The use of these new learning technologies in schools could demonstrate a positive impact on higher-order thinking skills and cognitive abilities. Appropriately deployed technologies can support exploration and help students to obtain achievable goals, to form and to test hypotheses, and to discover new knowledge. These constructivist applications of technologies support developing higher-order thinking skills that can help students to strive and succeed with real, open-ended questions, such as those that they will have to face, address and deal with during their adult lives.

\section{Conclusion}

As schools have greater access to various forms of learning technologies for teaching and learning, these technological advancements afford numerous opportunities for nurturing students' 21 st century skills, in particular, the collaborative learning and independent learning, exploitation of these affordances hinges on teachers' capacity to design learning tasks and facilitate students' learning experiences. It is therefore recommended that teachers have to be better equipped with the pedagogical skills in deploying these tools appropriately for effective collaborative and independent learning.

\section{References}

AKAR, H. Impact of constructivist learning process on preservice teacher education students' performance, retention, and attitudes. Dissertation (Doctoral) - Middle East Technical University, Ankara, 2003.

ANDREWS, J.; GARRISON, D. R.; MAGNUSSON, K. The teaching and learning transaction in higher education: a study of excellent professors and their students. Teaching in Higher Education, n. 1, p. 81-103, 1996. 
BARR, R. B.; TAGG, J. From teaching to learning: a new paradigm for undergraduate education. Change, v. 27, n. 6, p. 12-25, 1995.

BARROWS, H. S. A taxonomy of problem-based learning methods. Medical Education, n. 20, p. 481-486, 1986.

BARROWS, H. S. Problem-based learning applied to medical education. Springfield, IL: Southern Illinois University School of Medicine, 2000.

BOUD, D.; FELETTI, G. The challenge of problem-based learning. 2nd ed. London: Kogan Page, 1997.

COGNITION AND TECHNOLOGY GROUP AT VANDERBILT. Anchored instruction and situated cognition revisited. Educational Technology, v. 33, n. 3, p. 52-70, 1993.

DEPORTER, B.; HERNACKI, M. Quantum pathways: discovering your personal learning style. Oceanside, CA: Learning Forum Publications, 2000.

DODGE, B. WebQuest Page. 2002. Disponível em: <http://webquest.sdsu. edu>. Acesso em: 15 Dec. 2009.

GIBBS, G. Improving the quality of student learning through course design. In: BARNET'T, R. (Ed.). Learning to effect. Buckingham: SRHE/Open Press, 1992. p. 149-168.

HAND, B.; TREAGUST, D. F; VANCE, K. Student perceptions of the social constructivist classroom. Science Education, n. 81, p. 561-575, 1997.

JONASSEN, D. H. Computers in the classroom: mind tools for critical thinking. Englewood Cliffs, NJ: Prentice-Hall, Inc, 1996.

$\mathrm{KOH}, \mathrm{N}$. K. The authentic evaluation of teachers using the mixed mode assessment model. In: INTERNATIONAL CONFERENCE ON TEACHING AND LEARNING IN HIGHER EDUCATION - ICTLHE, 1., 2004, NUS, Singapore. Proceedings... NUS, Singapore: iCTLHE, 2004.

LOOI, C.-K.; HUNG, D.; BOPRY, J.; KOH, T.-S. Singapore's learning sciences lab: Seeking transformations. ICT-Enabled Pedagogy. Educational Technology Research and Development, v. 52. n. 4, p. 91-99, 2004.

MCKENZIE, J. Beyond technology: questioning, research and the information literate school. Bellingham, WA: FNO Press, 2000. 
MINISTRY OF EDUCATION - MOE. Recognizing school achievements in 2008. Disponível em: <http://www.moe.gov.sg/media/press/2008/09/ recognising-school-achievement.php>. Acesso em: 29 Dec. 2009.

NG, E. H. Opening Address by Minister for Education and Second Minister for Defence. In: INTERNATIONAL CONFERENCE ON TEACHING AND LEARNING WITH TECHNOLOGY - ICTLT, 1., 2008, Singapore. Proceedings... Singapore: iCTLT, 2008.

RAINER, J. D.; MATTHEWS, N. M. Ownership of learning in teacher education. Action in Teacher Education, v. 24. n. 1, p. 22-30, 2002.

TAN, O. S. Enhancing thinking through problem-based learning approaches. Singapore: Thomson Learning, 2004.

TOBIN, K.; TIPPINS, D. J. Constructivism as a referent for teaching and learning. In: TOBIN, K. (Ed.). The practice of constructivism in science education. Hillside, NJ: Lawrence Erlbaum \& Associates, 1993. p. 3-21.

YLANNE, S. L.; LONKA, K. Individual ways of interacting with the learning environment - Are they related to study success? Learning and Instruction, n. 9, p. 1-18, 1999.

Received: 04/20/2010

Recebido: 20/04/2010

Approved: 06/23/2010 Aprovado: 23/06/2010 